\title{
AKTIFITAS KEPEMIMPINAN KEPALA MADRASAH DALAM MENINGKATKAN MOTIVASI KERJA GURU DI MADRASAH IBTIDAIYAH NEGERI POJOK PONGGOK BLITAR
}

\author{
Muh. Hamzah Sururi \\ Program Studi Pendidikan Agama Islam Pascasarjana IAI Tribakti Kediri
}

\begin{abstract}
Abstrak.
Fokus penelitian ini adalah untuk endeskripsikan. bagaimana aktifitas kepemimpinan kepala madrasah, motivasi kerja guru, dan kontribusi kepemimpinan kepala madrasah dalam meningkatkan motivasi kerja guru di MIN Pojok. Pendekatan penelitian yang digunakan termasuk jenis penelitian kualitatif. Yang memiliki ciri-ciri antara lain : latar alami, peneliti sebagai instrument kunci, dan penelitiannya bersifat deskriptif. Dalam pengumpulan datanya peneliti menggunakan metode wawancara, observasi dan dokumentasi, dimana ketiganya tersebut merupakan komponen yang tidak dapat terpisahkan guna memperoleh data dalam penelitian. Untuk analisis datanya peneliti menggunakan reduksi data atau penyederhanaan (data reduction), paparan data atau sajian data (data display), dan penarikan kesimpulan (conclusion verifiying). Hasil penelitian menunjukkan bahwa, 1) Aktifitas kepemimpinan kepala madrasah dalam meningkatkan motivasi guru antara lain: menciptakan kebersamaan diantara guru, menciptakan rasa aman dan nyaman dilingkungan madrasah, memberikan sugesti positif kepada para guru, mengadakan pendidikan dan pelatihan bagi guru, menyediakan kebutuhan dalam menunjang kegiatan belajar mengajar. 2) Motivasi kerja guru di MIN Pojok secara umum sudah baik, dilihat dari tingkat kehadiran guru dimadrasah, keaktifan guru dalam pembelajaran dikelasdan diluar kelas, pembuatan perangkat pembelajaran yang sudah siap sebelum pengajaran, melakukan penilaian dan analisis hasil ulangan siswa 3) Kontribusi kepemimpinan kepala madrasah dalam meningkatkan motivasi kerja guru di MIN Pojok antara lain: kepala madrasah menerapkan manajemen terbuka, menerapkan sistem pembagian tugas dan tanggung jawab, menjalin hubungan yang baik terhadap guru dan karyawan, melakukan pengawasan secara berkesinambungan, melakukan evaluasi terhadap uraian tugas dan dokumen dan memberikan koreksi dan masukan jika terjadi kesalahan
\end{abstract}

\section{Kata Kunci : Aktifitas Kepemimpinan Kepala Madrasah, Motivasi Kerja Guru}

\section{Pendahuluan}

Kepala madrasah memiliki peranan penting dalam meningkatkan kemajuan madrasah. Untuk itu diperlukan sebuah motivasi yang tinggi dalam memimpin. Di samping itu diperlukan visi dan misi yang jelas untuk menggerakkan bawahanya. Sehingga sejumlah guru dan tenaga kependidikan lainya memiliki arah yang jelas demi kemajuan madrasah.

Untuk kepentingan tersebut kepala madrasah selayaknya mampu memobilisasi atau memberdayakan semua potensi dan sumber daya yang dimiliki, terkait dengan berbagai program, proses, evaluasi, pengembangan kurikulum, pembelajaran di madrasah, pengolahan tenaga kependidikan, sarana prasarana, pelayanan terhadap siswa, hubungan dengan masyarakat, sampai pada penciptaan iklim madrasah yang kondusif. Semua ini akan terlaksana manakala kepala madrasah memiliki kemampuan untuk mempengaruhi semua pihak yang terlibat dalam kegiatan pendidikan dimadrasah, yaitu untuk bekerjasama dalam mewujudkan tujuan madrasah.

Di lain pihak terdapat faktor yang juga menjadi salah satu penentu keberhasilan tujuan pendidikan di madrasah yaitu guru. Guru mempunyai tugas untuk mendidik, mengajar dan 
melatih. Mendidik berarti meneruskan dan mengembangkan nilai-nilai hidup, mengajar berarti meneruskan dan mengembangkan ilmu pengetahuan, melatih berarti mengembangkan keterampilan-keterampilan pada siswa. Dalam melaksanakan tugas dan tanggung jawab tersebut, seorang guru dituntut memiliki beberapa kemampuan dan keterampilan tertentu. Kemampuan dan keterampilan tersebut sebagai bagian dari kualitas guru.

Malayu Hasibuan menjelaskan bahwa Motivasi penting karena dengan motivasi ini diharapkan setiap individu karyawan mau bekerja keras dan antusias untuk mencapai produktivitas yang tinggi. ${ }^{1}$

Motivasi mempersoalkan bagaimana caranya mendorong gairah kerja guru, agar guru mau bekerja keras dengan menyumbangkan segenap kemampuan, pikiran, keterampilan dalam rangka mewujudkan tujuan pendidikan. Dalam motivasi terdapat suatu kekuatan potensial yang ada pada diri seseorang, yang dapat dikembangkan sendiri, atau dikembangkan oleh sejumlah kekuatan luar, yang dapat mempengaruhi kinerjanya secara positif atau negatif. Hal mana tergantung pada situasi dan kondisi yang dihadapi orang yang bersangkutan. Ketika seseorang bekerja kurang bergairah atau tanpa motivasi, keinginan untuk memperoleh hasil yang baik sepertinya patut diragukan, dan sebaliknya bekerja dengan gairah atau motivasi kerja yang tinggi harapan untuk memperoleh hasil yang baik banyak menjadi pemahaman orang.

Bagi guru, motivasi yang dimilikinya, dilapangan dipercaya akan dapat menggerakkan atau memacu peserta didiknya agar timbul kemauan dan keinginan untuk meningkatkan prestasi belajar sehingga tujuan pendidikan tercapai sesuai dengan apa yang diharapkan dan ditetapkan madrasah.

Sebuah motivasi erat kaitannya dengan tujuan, harapan atau cita-cita seseorang. Makin berharga sebuah tujuan makin kuat pula motivasi, jadi motivasi

1 Malayu Hasibuan SP (2007), Manajemen Sumber Daya Manusia , Bumi Aksara, Jakarta, hlm. 92 sangat bermakna bagi tindakan seseorang. Berdasarkan pemahaman ini, kegunaan atau fungsi dari motivasi dalam kehidupan seseorang sebagai pendorong agar melaksanakan sesuatu, menentukan arah perbuatan sehingga dapat meningkatkan hasil kerja, mempercepat proses penyelesaian pekerjaan, dan sarana pengembangan prestasi kerja dan pencapaian tujuan organisasi.

Agar penelitian ini terarah dan lebih focus maka penelitian ini menitik beratkan pada studi tentang Kepemimpinan Kepala Madrasah dalam meningkatkan motivasi kerja guru. Studi tentang kepemimpinan kepala madrasah, diteliti dengan mengadakan observasi, survey dan wawancara mendalam dengan berbagai responden, serta dalam rangka memperkuat analisis ditentukan pendapat atau persepsi guru yang berada di bawah kepemimpinannya.

Dari konteks penelitian diatas, penelitian ini akan difokuskan pada persoalan yang menurut peneliti cukup penting untuk dikaji secara mendalam yakni:1. Bagaimana aktivitas kepemimpinan kepala madrasah di MIN Pojok. 2. Bagaimana motivasi kerja guru di MIN Pojok. 3. Apa kontribusi kepemimpinan kepala madrasah dalam meningkatkan motivasi kerja guru di MIN Pojok. Kepemimpinan Kepala Madrasah

\section{Kajian Pustaka}

Kepemimpinan berusaha untuk membuat perubahan dalam organisasi dengan (1) menyusun visi masa depan dan strategi untuk membuat perubahan yang dibutuhkan, (2) mengkomunikasikan dan menjelaskan visi (3) memotivasi dan memberi inspirasi kepada orang lain untuk mencapai visi itu ${ }^{2}$

Teori Great Man baru dapat memberikan arti lebih realistis terhadap pendekatan sifat dari pemimpin, setelah mendapat pengaruh dari aliran perilaku pemikir psikologi, yang menegaskan bahwa dalam kenyataanya sifat-sifat

2 Yukl, Gary (2010), Kepemimpinan Dalam Organisasi. Edisi ke Lima ( Budi Supriyanto, Penerjemah ), Indeks , Jakarta, hlm.3 
kepemimpinan itu tidak seluruhnya dilahirkan, tetapi dapat juga dicapai melalui pendidikan dan pengalaman. Oleh karenanya perhatian terhadap kepemimpinan dialihkan kepada sifat-sifat umum yang dimiliki oleh pemimpin, tidak menekankan apakah pemimpin dilahirkan atau dibuat. Oleh karena itu sejumlah sifatsifat seperti fisik, mental, kepribadian menjadi pusat perhatian untuk diteliti.

Dari hasil penelitian yang dilakukan oleh pera peneliti dapat disimpulkan bahwa diantara sifat-sifat yang cenderung mempengaruhi timbulnya kepemimpinan antara lain adalah kecerdasan, inisiatif, keterbukaan, antusiasme, kejujuran, simpati, dan kepercayaan pada diri sendiri. Namun tidak semua sifat-sifat tersebut bisa diterapkan pada semua bidang, terutama pada organisasi, dikatakan bahwa keberhasilan seorang manajer tidak semata-mata dipengaruhi oleh sifat-sifat tadi, artinya tidak selalu ada hubungan sebab akibat dari sifat yang diteliti diatas dengan keberhasilan seorang manajer.

Akhirnya kesimpulan dari teori sifat ini diketahui bahwa tidak selalu ada korelasi sebab akibat antara sifat dan keberhasilan manajer, sehingga mendorong Keith Davis yang disarikan oleh Miftah Thoha merumuskan empat sifat umum yang mempengaruhi terhadap keberhasilan kepemimpinan organisasi, yaitu:

\section{1) Kecerdasan}

Hasil penelitian pada umumnya membuktikan bahwa pemimpin mempunyai tingkat kecerdasan yang lebih tinggi dibandingkan dengan yang dipimpin. Namun demikian, yang sangat menarik dari penelitian tersebut ialah pemimpin tidak bisa melampaui terlalu banyak dari kecerdasan pengikutnya.

\section{2) Kedewasaan dan keluasan hubungan sosial.}

Pemimpin cenderung menjadi matang dan mempunyai emosi yang stabil, serta mempunyai perhatian yang luas terhadap akitivitas-aktivitas sosial. Dia mempunyai keinginan menghargai dan dihargai.

\section{3) Motivasi diri dan dorongan berprestasi.}

Para pemimpin secara realatif mempunyai dorongan motivasi yang kuat untuk berprestasi. Mereka bekerja berusaha mendapatkan penghargaan yang intrinsik dibandingkan dari yang ekstrinsik.

\section{4) Sikap sikap hubungan kemanusiaan.}

Pemimpin-pemimpin yang berhasil mau mengakui harga diri dan kehormatan pengikutnya dan mampu berpihak kepadanya. Dalam istilah penelitian Universitas Ohio pemimpin itu mempunyai perhatian dan kalau mengikuti istilah penemuan michigan pemimpin itu berorientasi pada karyawan bukanya beorientasi pada produksi.

\section{Kepala Madrasah}

Untuk dapat merealisasikan tugas dan fungsi kepemimpinan, kepala madrasah sebagai seorang pemimpin pendidikan Kepala Sekolah dapat memahami langkah-langkah kepemimpinan seperti yang dirumuskan oleh departemen pendidikan nasional sebagai berikut: tahu tugas pokok sendiri, tahu jumlah pembantunya, tahu nama-nama pembantunya, tahu masing-masing pembantunya, memperhatikan kehadiran pembantunya, memperhatikan peralatan pembanntunya, menilai pembantunya, mengambil tindakan-tindakan, memperhatikan karir pembantunya, memperhatikan kesejahteraan pembantunya, memperhatikan suasana kekeluargaan, memberikan laporan kepada atasannya.

Untuk memenuhi tugas-tugas diatas, dalam segala hal hendaknya Kepala Sekolah berpegangan kepada teori sebagi pembimbing tindakannya. Teori ini didasarkan pada pengalamannya, karakteristik normatif masyarakat dan sekolah, serta iklim instruksional dan organisasi sekolah.

\section{Motivasi Kerja}

Motivasi yang ada pada diri setiap orang memiliki ciri-ciri sebagai berikut: Tekun menghadapi tugas, ulet menghadapi kesulitan, menunjukan minat terhadap 
bermacam-macam masalah, lebih senang bekerja sendiri, cepat bosan pada tugastugas yang rutin, dapat mempertahankan pendapatnya, tidak pernah mudah melepaskan hal yang diyakini, senang mencari dan memecahkan masalah soalsoal. Orang yang bermotivasi tinggi punya ciri-ciri tersendiri diantaranya yaitu: optimis, berani menerima tantangan, mandiri dan bertanggung jawab, mempunyai gairah hidup, memiliki citacita,selalu sibuk dengan aktifitas, kreatif, menikmati hidup, berfikir positif, dan mencari hikmah. Apapun yang terjadi diambil hikmahnya saja. Kegagalan adalah bagian dari proses belajar. Mereka belajar untuk memperbaiki diri dari kegagalan yang terjadi. Selalu ada hikmah dibalik semua peristiwa. Ambilah hikmah itu dan jadilah orang yang lebih baik.

Dengan demikian dapat disimpulkan bahwa seseorang yang memiliki motivasi kerja yang tinggi, memiliki ciri-ciri diatas, apabila seseorang memiliki ciri-ciri tersebut, berarti orang itu mempunyai motivasi kerja yang cukup tinggi.

\section{Metode Penelitian}

Peneliti ini menggunakan metode penelitian Kualitatif, yang mana menurut margono yang mengacu pada pendapat Bodgan dan Taylor, penelitian kualitatif adalah prosedur penelitian yang menghasilkan data deskriptif berupa katakata tertulis dari orang-orang dan perilaku yang dapat di amati. ${ }^{3}$

Selain itu dalam penelitian ini, peneliti sebagai instrumen kunci (research as key instrument); yaitu peneliti mengumpulkan sendiri data melalui dokumentasi, observasi perilaku, atau wawancara dengan para partisipan. ${ }^{4}$ Sementara analisis datanya menggunakan tiga langkah yaitu reduksi data, display data dan penarikan kesimpulan.

3 Margono.S (2009), Metode Penelitian Pendidikan, Rineka Cipta, Jakarta,36.

4Jhon W. Creswell (2010), RESEARCH DESIGN: Pendekatan Kulitatif, Kuantitatif, Dan Metode Campuran, PUSTAKA BELAJAR, Yogyakarta, 261.

\section{Hasil Penelitian}

\section{Aktifitas Kepemimpinan Kepala Madrasah di MIN Pojok}

Dalam menciptakan kebersamaan diantara warga madrasah kepala madrasah MIN Pojok memprogramkan budaya bersalaman setiap pagi antara semua warga madrasah baik guru, karyawan maupun siswa, membiasakan sholat dhuha dan dhuhur secara berjamaah kepada semua warga madrasah yang dilaksanakan pada waktu jam istirahat, membentuk team teaching antar guru, memberikan breafing kepada para guru dan karyawan setiap pagi, mengadakan rapat rutin yang dilaksanakan setiap satu minggu sekali untuk informasi dan evaluasi kegiatan yang telah terlaksana, setiap tahun menyelenggarakan manasik haji bagi semua warga madrasah. Dengan programprogram tersebut kebersamaan antar warga madrasah akan tercipta.

Dalam menciptakan rasa aman dan nyaman dilingkungan madrasah, kepala madrasah MIN Pojok telah membuatkan pagar madrasah, yang pagar tesebut ditutup ketika jam pembelajaran berlangsung, mengangkat penjaga madrasah dan petugas keamanan madrasah yang bertanggung jawab menjaga keamanan dilingkungan madrasah dan bertugas menyeberangkan siswa ketika datang dan pulang madrasah, membiasakan saling menghargai dan mempercayai antar warga madrasah sehingga tidak ada yang saling mencurigai.

Memberikan saran, anjuran dan sugesti yang positif untuk meningkatkan semangat para guru, staff dan karyawan dengan mengimbau agar menggunakan kata-kata yang halus dan bijak, dan tidak boleh menggatakan anak nakal kepada para siswa, yang nantinya menimbulkan efek yang negatif pada proses pembentukan karakter siswa.

Menyediakan kebutuhan guru dalam rangka menunjang kegiatan belajar mengajar, seperti halnya bahan untuk membuat media pembelajaran, dengan menghimbau kepada para guru untuk mengajukan anggaran terkait peralatan dan kelengkapan yang berhubungan 
dengan kegiatan belajar mengajar.

Memberikan perhatian dan penghargaan kepada hasil kinerja dan prestasi yang diraih oleh guru dengan memberikan reward berupa pujian dan ucapan selamat atas prestasi yang diraih.

\section{Gambaran Motivasi Kerja Guru di MIN Pojok}

Motivasi kerja guru MIN Pojok Ponggok Blitar dilihat dari tingkat kehadiran guru dimadrasah pada umumnya sudah baik, meskipun masih ada beberapa guru yang masih datang terlambat dengan beberapa alasan. Ada yang alasan keterlambatannya karena ban sepeda motornya bocor, ada yang keterlambatannya karena anaknya dirumah sedang sakit.

Guru di MIN Pojok pada umumnya sudah melaksanakan tugas dan tanggung jawab sebagai guru dengan baik, hal ini dibuktikan dengan membuat perangkat pembelajaran sebelum melakukan pembelajaran, melaksanakan pembelajaran kepada siswa dengan kreatif, hal ini terbukti dalam melalukan pembelajaran tidak hanya monoton didalam kelas, akan tetapi ada kalanya pembelajaran dilakukan diluar kelas dengan memanfaatkan lingkungan sebagai sumber belajar. dan melakukan evaluasi dan analisis hasil ulangan setiap akhir pelajaran selesai. Hal ini dibuktikan dengan dokumen-dokumen perangkat pembelajaran yang dimiliki oleh guru MIN Pojok.

Guru di MIN Pojok pada umumnya sudah aktif dalam meningkatkan kualitas pendidikannya. Hal ini dibuktikan banyak guru MIN Pojok yang mengikuti perkuliahan lagi menyesuaikan dengan tugasnya yang mengajar sebagai guru kelas. Ada juga yang menempuh pendidikan pasca sarjana. Disamping itu guru di MIN Pojok juga berrperan aktif mengikuti pendidikan dan pelatihan dan workshop yang berhubungan dengan pendidikan dan pembelajaran yang diselenggarakan oleh lembaganya maupun pendidikan dan pelatihan maupun workshop yang diselenggarakan diluar lembaga.
Dari beberapa gambaran diatas dapat ditarik kesimpulan bahwa tingkat motivasi kerja guru di MIN Pojok sudah tinggi hanya saja masih ada beberapa guru yang memiliki motivasi sedang.

\section{Kontribusi Kepemimpinan Kepala Madrasah dalam Meningkatkan Motivasi Kerja Guru di MIN Pojok Ponggok}

Kepala MIN Pojok Ponggok dalam meningkatkan motivasi kerja guru dengan menerapkan manajemen terbuka dengan menerima masukan, kritik dan saran dari semua pihak untuk peningkatan kualitas pendidikan dan pembelajaran diMIN Pojok.

Menerima masukan maupun usulan yang sebelumnya dipertimbangkan dan dimusyawarahkan dahulu pada forum musyawarah antar guru dan karyawan sebelum usulan maupun masukan diolak ataupun dilaksanakan.

Menerapkan pembagian tugas dan tanggung jawab kepada guru dengan membentuk bidang-bidang antara lain : PKM bidang Kurikulum, PKM bidang Humas, PKM bidang Kesiswaan, PKM bidang Saranan dan prasarana. Semua bidang memiliki tugas dan tanggung jawab berbeda dan berkewajiban melaporkan kinerjanya kepada kepala MIN Pojok.

Dengan dibentuknya PKM-PKM tersebut tugas dan tanggung jawab kepala madrasah akan semakin ringan dan mudah sehingga program-program madrasah akan semakin mudah terealisasikan.

Kepala MIN Pojok menerapkan hubungan yang baik kepada para bawahannya. Agar para guru bersedia melaksanakan tugas dengan sebaikbaiknyaa, memupuk kesetiaan tanggung jawab kepada pimpinan dan lembaga.

Kepala MIN Pojok membuat program-program kegiatan untuk meningkatkan motivasi kerja guru meliputi briefing, penghargaan bagi guru yang berprestasi , kesejahteraan para guru, peningkatan SDM, mendelegasikan untuk mengikuti pendidikan dan pelatihan dan workshop tentang pendidikan dan pembelajaran.

Kepala MIN Pojok melakukan pengawasan yang bersifat berkesinambu- 
ngan yang meliputi seluruh aspek yaitu: personil, pelaksanaan kegiatan, materi dan hambatan-hambatan dalam kegiatan

Kepala MIN Pojok melakukan evaluasi meliputi evaluasi terhadap uraian tugas, bukti-bukti dokumen-dokumen. Dan memberikan masukan dan koreksi jika ada kesalahan dan yang kurang sesuai dengan criteria yang diharapkan. Kepala madrasah memberikan solusi terhadap hambatanhambatan tersebut.

\section{Kesimpulan}

1. Aktifitas Kepemimpinan kepala madrasah dalam pengembangan motivasi kerja di MIN Pojok ini berada dalam kategori cukup baik hal tersebut dapat dilihat dari fungsi kepemimpinan kepala madrasah yang sudah berjalan yaitu dalam menciptakan kebersamaan diantara guru, Kepala madrasah memprogramkan budaya bersalaman antar warga madrasah setiap pagi ketika datang disekolah, kepala madrasah mengadakan briefing kepada guru setiap pagi, membentuk Team Teaching guru, membiasakan sholat dhuha dan dhuhur secara berjamaah, setiap tahun mnyelenggarakan kegiatan manasik haji bagi semua warga madrasah.

Menciptakan rasa aman dan nyaman di lingkungan madrasah dengan adanya 4 prinsip MIN Pojok yaitu disiplin, meghargai, kreatif dan peduli lingkungan. Kepala madrasah mengangkat penjaga madrasah dan petugas keamanan yang bertugas menjaga keamanan dilingkungan madrasah, menyeberangkan jalan siswa ketika datang dan pulang . Memasang pagar madrasah yang ditutup ketika proses belajar mengajar berlangsung.

Kepala madrasah selalu memberikan sugesti positif kepada para guru dalam proses pembelajaran kepada siswa. Menghimbau agar menggunakan kata-kata yang halus dan bijak kepada para siswa, larangan penggunaan kata-kata yang negative kepada siswa yang nantinya bisa berpengaruh dalam pembentukan karakter siswa.

Memberikan dukungan dan menyediakan apa saja yang diperlukan oleh para guru yang berhubungan dengan kegiatan belajar mengajar yaitu dengan menanyakan kepada guru tentang media apa yang dibutuhkan untuk kegiatan pembelajaran.

2. Motivasi kerja guru di MIN Pojok Ponggok pada umumnya sudah baik hal ini dibuktikan dengan aktifnya guru dalam kegiatan pembelajaran dimadrasah, kehadiran guru dimadrasah yaitu sebelum pembelajaran dimulai guru sudah hadir dan menyambut kedatangan anak-anak dengan bersalaman dengan anak-anak, dan dari dokumen perangkat pembelajaran yang meliputi: Perencanaan pembelajaran/ RPP, silabus, Kriteria Ketuntasan Minimal (KKM) yang sudah siap sebelum dipembelajaran dikelas, dan para guru melakukan penilaian dan analisis hasil ulangan siswa.

3. Kontribusi Kepemimpinan kepala madrasah terhadap meningkatkan motivasi kerja guru di MIN Pojok Ponggok antara lain :

a. Kepala madrasah menerapkan menejemen terbuka dalam kepemimpinannya

b. Kepala madrasah menerapkan pembagian tugas dan tanggung jawab kepada para guru

c. Kepala madrasah menerapkan hubungan vertical kebawah, yaitu menjalin hubungan baik dengan para guru dan karyawan

d. Kepala madrasah melakukan pengawasan secara berkesinambungan dan menyeluruh yang meliputi seluruh aspek yaitu: personil, pelaksananaan kegiatan, materi dan hambatan-hambatan yang dialami.

e. Kepala madrasah melakukan evaluasi meliputi evaluasi terhadap uraian tugas dan evaluasi bukti-bukti dokumen, dengan cara melihat langsung terhadap bukti-bukti tugas 
yang telah dilakanakan oleh guru kemudian memberikan masukan apabila terdapat kesalahan atau kurang sesuai dengan kriteria yang diharapakan.

\section{Saran-saran}

Berdasarkan paparan dan kesimpulan diatas, maka penulis menyampaikan saran sebagai berikut :

1. Karena kepemimpinan kepala madrasah dalam meningkatkan motivasi kerja guru di MIN Pojok berada dalam kategori cukup baik, maka bagi kepala madrasah MIN Pojok untuk terus meningkatkan kepemimpinannya dari segi fungsi kepemimpinan yaitu menciptakan kebersamaan diantara guru dan karyawan, Menciptakan rasa aman didalam lingkungan madrasah, Memberikan saran, anjuran dan sugesti untuk memelihara serta meningkatan semangat para guru staff dan siswa, Bertanggung jawab memenuhi dan menyediakan dukungan yang diperlukan oleh para guru, Sebagai motivator, dalam arti mampu menimbulkan dan menggerakkan semangat para guru, dan staf, Selalu dapat memperhatikan, menghargai apapun yang dihasilkan oleh para guru dan staf.

2. Kontribusi Kepemimpinan kepala madrasah dalam pengembangan motivasi kerja guru yang harus ditingkatkan adalah pemberian reward atas segala yang dihasilkan oleh para guru dan staf,. Akan lebih menyenangkan manakala reword dalam bentuk financial untuk lebih meningkatkan motivasi kerja guru.

\section{Daftar Pustaka}

Abdurrahman, A. (2004) Teori Pengembengan dan Filosifi Kepemimpinan Kerja. Ikhtiar Baru, Jakarta.

Dadang, S. (2010) Supervisi Profesional Layanan Meningkatkan Mutu
Pembelajaran di Era Otonomi Daerah. Alfabeta, Bandung.

Dirawat dkk. (1983) Pengantar Kepemimpinan Pendidikan. Usaha Nasional, Surabaya.

Hasibuan, M.S.P. (2007) Manajemen Sumber Daya Manusia. Bumi Aksara, Jakarta.

Komang, A. ( 2008) Perilaku Keorganisasian. Graha Ilmu, Yogyakarta

Kartono, K. (2010) Pemimpin dan Kepemimpinan, Apakah Kepemimpinan Abnormal itu? Rajawali Pers, Jakarta.

Mulyasa (2003) Menjadi Kepala Madrasah Profesional Dalam Konteks Menyukseskan MBS dan KBK. Rosda, Bandung.

Purwanto, N (1991), Administrasi dan Supervisi Pendidikan. Remaja Rosda karya, Bandung.

Purwanto, N. (1992) Kepemimpinan Yang Efektif. Gadjah Mada University Press, Yogyakarta.

Rivai, V. (2004), Memimpin Dalam Abad ke21. PT. Raja Grafindo Persada, Jakarta.

Suhendra, K. (2008) Manajemen dan Organisasi Dalam Realita Kehidupan, CV. Mandar Maju, Bandung

Sukanto, R. dan Handoko, H.T. (2000) Organisasi Perusahaan: Teori, Struktur dan Perilaku. BPFE, Yogyakarta.

Suyanto, dan Hisam, D. ( 2000) Refleksi dan Reformasi Pendidikan Indonesia Memasuki Millenium III. Adi, Yogyakarta.

Sulton. M (2009) Membangun Semangat Kerja Guru. LaksBang PRESS indo, Yogyakarta. 
Suprayogo, I (1999) Revolmulasi Visi Pendidikan Islam. STAIN Press, Malang.

Sulistyorini (2001) Hubungan Antara Manajerial Kepala Madrasah Dan Iklim Organisasi Dengan Kinerja Gur. Jurnal Ilmu Pendidikan, Th 28 no.1 Januari 200.

Thoha, M. (2010) Kepemimpinan Dalam Manajemen. Raja Grafindo Persada Jakarta.

Wahjosumidjo (2002) Kepemimpinan Kepala Madrasah tinjauan teoritik dan permasalahan. PT. Raja Grafindo Persada, Jakarta.

Yunus. (2007) Kepemimpinan Pendidikan. Unigal, Ciamis. 